\title{
Analysis of the use of fenthion via epicutaneous in dogs for Rhipicephalus sanguineus control
}

\author{
Análise do uso de fenthion via epicutânea em cães \\ para o controle de Rhipicephalus sanguineus
}

Fernando de Freitas Fernandes ${ }^{1}$ and Edméia de Paula e Souza Freitas ${ }^{2}$

\begin{abstract}
The action of fenthion was studied in a 15\% epicutaneous formulation upon Rhipicephalus sanguineus, which may transmit pathogens to men and other animals, such as Ehrlichia, Babesia and Ricketsia. Dogs were artificially infected for the trial. The fenthion bioassays were begun four months after artificial infestation. The test group, having a mean of 186 ticks per dog, received the formulation dosage according to body weight on the neck region. Tick counts were performed, considering diameters $\geq 2 \mathrm{~mm}$, during 11 days of treatment, in the most affected body areas: back, ears and paws. Before the application of fenthion in the dogs, it were observed an average $43.3 \%$ ticks in the ears, $38.1 \%$ in the back area and $17.6 \%$ in the paws. The number of ticks in dogs decreased by $36.2 \%, 63.8 \%, 82.7 \%, 67 \%, 40 \%$ and $4.9 \%$, respectively on days 1, 2, 3, 5, 7, 9 and 11 after treatment. R. sanguineus anti-tick activity, lower than that officially recommended, was verified. The number of ticks increased progressively after the $5^{\text {th }}$ day, demonstrating residual insecticide inefficacy. The results obtained did not indicate the use of this formulation, at the tested dosage, as an elective measure for R. sanguineus control. Key-words: Ixodidae. Tick. Rhipicephalus sanguineus. Control. Fenthion.
\end{abstract}

Resumo Investigou-se a atividade de fenthion em formulação epicutânea a 15\% sobre Rhipicephalus sanguineus, transmissor de patógenos ao homem e animais, tais como Ehrlichia, Babesia e Ricketsia. Infestouse artificialmente cães com larvas deste carrapato. Os bioensaios com o fenthion iniciaram-se 4 meses após a infestação artificial. Constatada a média de 186 ixodídeos/cão, cães do grupo teste receberam na região da nuca a dosagem correspondente ao seu peso. Avaliaram-se a eficiência e a atividade residual através de contagens dos carrapatos com diâmetro $\geq 2 \mathrm{~mm}$, durante 11 dias, nas áreas corpóreas mais parasitadas: dorso, orelhas e patas. Anteriormente, à aplicação do fenthion, 44,3\% dos carrapatos format observados nas orelhas, $38,1 \%$ na área estudada do dorso e $17,6 \%$ nas patas. Revelou-se uma redução do número de carrapatos nos cães de $36,2 \%, 63,8 \%, 82,7 \%, 67 \%, 40 \%$ e 4,9\%, respectivamente, nos dias 1, 2, 3, 5, 7, 9 e 11. Atividade carrapaticida menor do que a recomendada oficialmente foi constatada. O número de carrapatos aumentou progressivamente após o $5^{\circ}$ dia, denotando ineficácia carrapaticida residual. Os resultados obtidos impedem a indicação da formulação na dosagem testada como medida eletiva para controle de R. sanguineus.

Palavras-chaves: Ixodidae. Carrapato. Rhipicephalus. Controle. Fenthion.

Rhipicephalus sanguineus (Latreille, 1806) is an African tick, which became widespread throughout the world, following Man's activities, affecting especially domestic dogs, its principal host. Due to either its high biotic potential or the existence of environmental conditions which were favorable to its development, it established with high density or prevalence in several cities of the world ${ }^{17}$. This tick is involved in the transmission of protozoa, rickettsia, virus and filariae which cause illnesses to the animals and emergent diseases to man, although these are rarely lethal 562021232425262932 . Recently in the USA, studies have demonstrated that immature stages feeding on humans is more common than one would suppose ${ }^{19}$.
Tick control is usually carried out by applying acaricide onto the hosts, with the aim of impairing engorged females from laying eggs. In Brazil, few studies have been realized on Rhipicephalus sanguineus 8101112131431 . Because it is a 3-host tick, with a wide variety of hosts and having a great diversity of colonized environments, Rhipicephalus sanguineus control becomes difficult and expensive, requiring a great substructure including people and materials. Epicutaneous acaricides are a good tool for control, since they are easy to apply and reach larger areas within a lower time. Furthermore, it requires a smaller working team ${ }^{1}$.

\footnotetext{
1. Setor de Entomologia do Departamento de Microbiologia, Imunologia, Parasitologia e Patologia do Instituto de Patologia Tropical e Saúde Pública da Universidade Federal de Goiás, Goiânia, GO. 2. Estagiária em liniciação Científica.

Endereço para correspondência: Prof. Fernando de Freitas Fernandes. Setor de Entomologia/DMIPP/IPTSP/UFG. Caixa Postal 131, 74605-050 - Goiânia, GO. Fax: 5562 202-3066.

e-mail: ffreitas@iptsp.ufg.br.

Recebido para correspondência em 16/6/2000.
} 
Fenthion is an organophosphorad available on the market as an epicutaneous formulation, at a $15 \%$ concentration (spot-on), commercialized as an anti-flea product for dogs. This formulation allows rapid absorbency after application, in a few millimeters as a simple spot, on the animals' back skin, playing a systemic role ${ }^{13}$. Dog breeders from Goiânia - capital of the Brazilian State of Goiás - have observed that treating animals infected by fleas and ticks with the formulation reduced the number of both these ectoparasites. The aim of this study was to investigate the efficiency and residual activity of that product on Rhipicephalus sanguineus, administrated via epicutaneous in dogs in order to contribute to those strategies for its control.

\section{MATERIAL AND METHODS}

Female Rhipicephalus sanguineus, which were full of blood and naturally detached were collected in infested kennels from ten residences distributed in five districts of Goiânia. From each kennel, twelve engorged females were collected, these were found climbing walls, on the wooden roof and on the ground, hiding themselves in slits for laying eggs. They were placed inside polyethylene tubes $(3 \times 9 \mathrm{~cm}$, spiral cap) and transported to the laboratory for obtaining larvae, after incubation in a B.O.D. chamber at $27 \pm 1^{\circ} \mathrm{C}$ under relative humidity higher than $80 \%$. From the egglayings with the best indexes of hatching, verified according to the method described by Amaral $^{2}$, a pool of larvae was prepared, which was used for artificial infection, in an experimental kennel ${ }^{12}$. Dogs were chosen from both genders of no specific breed and varying ages, with a good nutritional status and free form acaricide residues.

The fenthion bioassays were begun four months after the artificial infestation and after verification of nymphs and adults on the dogs and in the environment. In fenthion bioassays, six dogs represented the test group and one dog that did not receive the drug was considered as the control. Test group dogs were weighed and divided into two groups, according to the dosage determined (2.0ml / 23 - 30kgb.w. and 1.5ml / 16 - 22kgb.w.). A 15\% epicutaneous fenthion solution was injected on the skin in the region of the neck.

In order to evaluate treatment efficacy and the product's residual activity, counts were made of the total number of ticks in each phase, considering diameters equal to or larger than $2.0 \mathrm{~mm}$, which were found on the animals on the day of treatment (day 0 ), and on days 1 , $2,3,5,7,9$ and 11 , following the product's use. The most affected corporal areas were chosen, including the back (a $100 \mathrm{~cm}^{2}$ area), the ears (inner surface), and the paws (spaces between fingers and cushions).

The Chi-square test $\left(\chi^{2}\right)$, at $5 \%$ significance level, was used in order to verify the influence of fenthion treatment on reducing the number of ticks in dogs ${ }^{7}$. The efficiency of the treatment was evaluated according to the Brazilian Ministry of Agriculture norms ${ }^{28}$, which establish $95 \%$ as the minimum mortality obtained for an ascaricide dosage to be recommended for use in the ixodids control.

\section{RESULTS}

The results are shown in (Figure 1). Artificial infestation was successfully achieved, causing either a

notable development or proliferation of ticks in the experimental kennel. The dogs were evaluated prior to

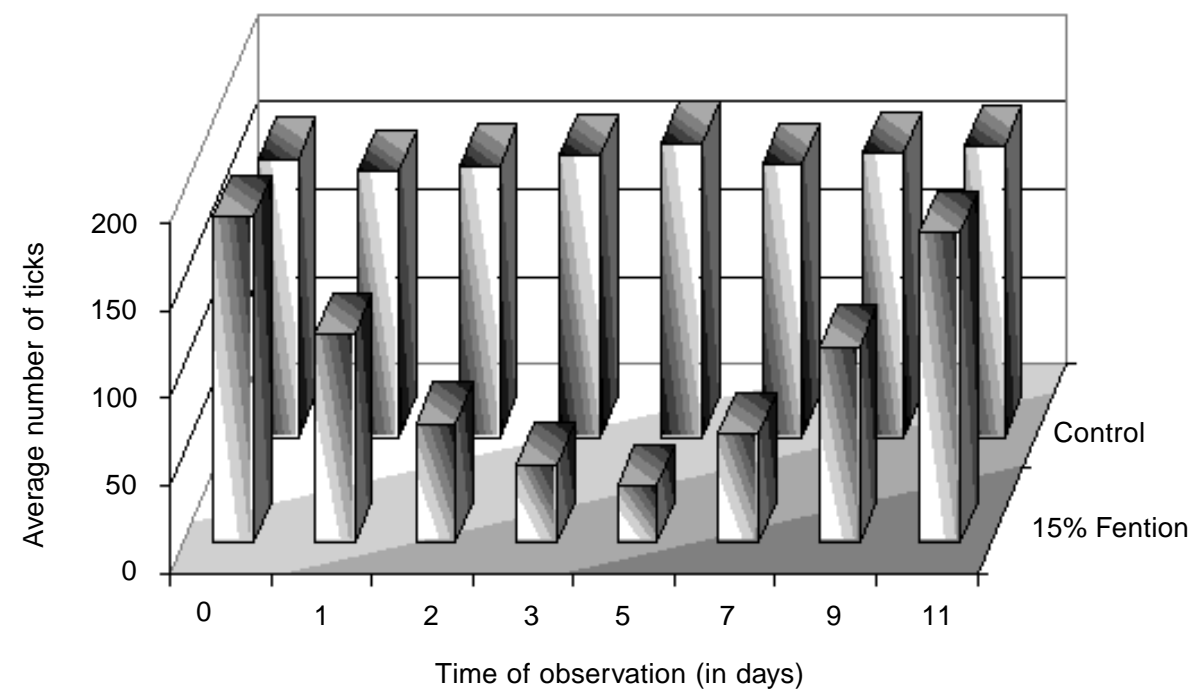

Figure 1 - Activity of fenthion $15 \%$ on Rhipicephalus sanguineus, applied in epicutaneous formulation on the dogs. 
application of fenthion, finding on average $44.3 \%$ of ticks in the ears (inner surface), $38.1 \%$ in the back area and $17.6 \%$ in the dog's paws (spaces between claws and pads). The counts on days $0,1,2,3,5,7,9$ and 11 showed a mean number of ticks of $186,118.64,67.37,44.25,32.18,61.34$, 111.60 and 176.96 in the test group and 159, 152, 155, $161,168,156,162$ and 166 in the control group, respectively. Statistical analysis demonstrated that elimination of ticks in the test group was significantly higher than that observed in control group $\left(\chi^{2}=50.09>\chi_{.05(1)}^{2}=3.84\right)$.
The percentage reduction in the number of ticks on the treated dogs was $36.2 \%, 63.8 \%, 76.2 \%$, $82.7 \%, 67 \%, 40 \%$ and $4.9 \%$, on days $1,2,3,5$, 7,9 and 11 respectively, following treatment. It was demonstrated that the anti-tick activity of epicutaneous $15 \%$ fenthion against $R$. sanguineus, achieved a progressive reduction in the number of ticks on dogs from the $1^{\text {st }}$ to $5^{\text {th }}$ day after application, however the results were lower than the $95 \%$ minimum level recommended for insecticides ${ }^{28}$.

\section{DISCUSSION}

Better results for $R$. sanguineus control, using epicutaneous pyrethroids, have been reported. Alcaíno et $\mathrm{a}^{\prime}$, employing epicutaneous cipermethrin, achieved an $87 \%$ tick reduction in dogs and a residual effect of 20 days. Ulloa et $a^{\beta 4}$, using epicutaneous Flumethrin, demonstrated tick reduction in dogs which was always higher than $85 \%$.

In New Caledonia, Boophilus microplus tick resistance against fenthion was reported by Beugnet $\&$ Chardonet ${ }^{4}$. Since in Brazil, the use of bovine anti-tick formulas on dogs is common ${ }^{11} 121314$, it may be possible that $R$. sanguineus fenthion resistance has already occurred, which could be detected by fastened larvae in vitro susceptibility tests ${ }^{1112} 16$.

However, there are reports of fenthion efficacy against Ctenocephalides felis fleas in cats, describing a reduction of $91.3 \%$ in animals treated every 28 days with this insecticide, 50 days following initial treatment ${ }^{15}{ }^{16}$. This index was higher than $80 \%$, which is recommended for insecticides by $\mathrm{WHO}^{35}$.

After the $5^{\text {th }}$ day, the number of ticks on the dogs progressively increased, demonstrating residual anti-tick inefficacy for $R$. sanguineus. The results obtained in the present trial did not support the choice of epicutaneous $15 \%$ fenthion in control campaigns against $R$. sanguineus, however, its use could be justified as an auxiliary procedure in a simultaneous control of fleas in the affected dogs, since it would then be associated to suitable methods for tick control. This hypothesis suggests that such procedures should not only consider tick control in dogs, but especially an eradication program against the tick's free life forms. Consequently, the authors suggest that some physical, semiochemical, biological or immunological alternative control measures, should be studied and adopted taking into consideration also the lowest environmental impact. Such methods may include the use of fire-broom on the infested surfaces (domestic flame-launching), to the use of semiochemical attracting traps ${ }^{18}$, associated with phyto-sanitary insecticides or acaricides ${ }^{33}$ or entomopathogenic microorganisms ${ }^{22}$, or the use of anti-tick vaccine ${ }^{27} 30$, obviously with an accompanying cost-benefit analysis.

\section{ACKNOWLEDGEMENT}

We are grateful to Prof. Tânia F.F. Gallé for critical review and suggestions on the translation of this manuscript.

\section{REFERENCES}

1. Alcaíno H, Gorman T, Acosta P, Fredes F. Evaluación de cinco esquemas de control con cipermetrina del Rhipicephalus sanguineus en la Región Metropolitana de Chile. Archivos de Medicina Veterinaria 27: 45-51, 1995.

2. Amaral NK. Guidelines for the evaluation against the cattle tick Boophilus microplus (Canestrini, 1887) (Acari:Ixodidae). Brazilian Journal of Veterinary Parasitology 2: 144-151, 1993.

3. Andrei E. Compêndio Veterinário - Indicador terapêutico dos produtos para Medicina Veterinária, $8^{a}$ edição. Organização Andrei Editora, São Paulo, 1991.

4. Beugnet F, Chardonnet L. Tick resistance to pyrethroids in New Caledonia. Veterinary Parasitology 56: 325-338, 1995.

5. Bucner RG, Ewin SA. Canine babesiasis. In: Kirk RW (ed) Current Veterinary Therapy IV. WS Saunders, Philadelphia p.673-679, 1971.

6. Burgdorfer, W, Sacristão DJ, Gerloff, RK, Anacker RL, Philip RN, Thomas LA. Rhipicephalus sanguineus: vector of a new spotted fever group rickettsia in the United States. Infection and Immunity 12: 205-210, 1975.
7. Centeno AJ, Kratz FL, D'Ayala Valva F, Monteiro MSR, Torres RAA, Chen LC. Curso de Estatística Aplicada à Biologia, CEGRAF/Universidade Federal de Goiás, Goiânia,1990.

8. Coelho CF. Biologia da Fase Não Parasitária de Rhipicephalus sanguineus (Latreille, 1806) (Acari, Ixodidae) sob condições de laboratório: aspectos da oviposição. Tese de Mestrado, Universidade Federal Rural do Rio de Janeiro, Rio de Janeiro, RJ, 1993.

9. Famadas KM, Mota CS. Órgão de Haller: caracterização morfológica e estruturas setiformes anexas presentes no tarso I da larva de Rhipicephalus sanguineus (Acari: Ixodidae). In: Anais do XVI Congresso Brasileiro de Entomologia, Salvador p.42, 1997.

10. Fernandes FF. Dispositivo experimental para manutenção de colônias de ixodídeos visando ao estudo dos parâmetros biológicos da fase de vida livre do ciclo evolutivo. Revista Goiana de Medicina 42: 43-48, 1997a.

11. Fernandes FF. In vitro activity of permethrin, cipermethrin and deltamethrin on larvae of Rhipicephalus sanguineus (Latreille, 
1806) (Acari, Ixodidae). Arquivo Brazileiro de Medicina Veterinária e Zootecnia 52: 621-626, 2000.

12. Fernandes FF, Freitas EPS, Silva JRV, Silva OR, Silva IG. Toxological effects and in vitro inefficacy of deltamethrin on larvae of Rhipicephalus sanguineus from Goiânia, Goiás, Brazil. Revista da Sociedade Brasileira de Medicina Tropical 34: 159-165, 2001.

13. Fernandes FF, Silva IG, Silva OR, Silva JRV, Gomes AG. Estudo da ação in vitro de piretróide sobre Rhipicephalus sanguineus (Acari, Ixodidae). Revista Brasileira de Parasitologia Veterinária 6: 153, 1997.

14. Fernandes FF, Silva OR, Silva JRV. Estudo da ação de cipermethrin $15 \%$ sobre larvas de Rhipicephalus sanguineus (Latreille, 1806) (Acari, Ixodidae). In: Resumos do XVII Congresso Brasileiro de Entomologia, VIII Encontro Nacional de Fitossanitaristas, Rio de Janeiro p.1076, 1998.

15. Fisher MA, Jacobs DE, Hutchinson MJ, Dick IG. Evaluation of flea control programmes for cats using fenthion and lufenuron. Veterinary Record 27, 138:79-81, 1996.

16. Food and Agriculture Organization of the United Nations (FAO). Acaricide resistance test kit. Instructions for use. World Acaricide Resistance Reference Centre, World Acaricide Resistence Center (WARRC), Edition 11, Berlin, Germany, 1995.

17. Fox MT, Sykes TJ. Establishment of the tropical dog tick, Rhipicephalus sanguineus, in a house in London. Veterinary Record 116: 661-662, 1985.

18. Hamilton JGC, Papadopoulus E, Harrison SJ, Lloyd CM, Walker AR. Evidence for a mounting sex pheromone in the brown ear tick Rhipicephalus appendiculatus, Neuman 1901 (Acari: Ixodidae). Experimental \& Applied Acarology 18: 331-338, 1994.

19. Harrison BA, Engber BR, Apperson CS 1997. Ticks (Acari: Ixodidae) uncommonly found biting humans in North Carolina. Journal of Vector Ecology 22: 6-12.

20. Heath A. Interception of the brown dog tick, Rhipicephalus sanguineus infesting man. New Zealand Veterinary Journal 34: 76-77, 1986

21. Hoogstraal H. Ticks. Ticks in relation to human diseases caused by rickettsia species. Annual Review of Entomology 12:377-420, 1967.

22. Kaaya GP, Mwangi EN, Ouna EA. Prospects for biological of Livestock Ticks, Rhipicephalus appendiculatus and Amblyomma variegatum, using the entomogenous fungi Beauveria bassiana and Metarhizium anisopliae. Journal of Invertebrate Pathology 67: 15-20, 1996

23. Kuehn NF, Gaunt SD. Clinical and haematological findings in canine erlichiosis. Journal American of Veterinary and Medical Association 186: 355-359, 1985.

24. Lemos ER, Machado RD, Coura JR, Guimaraes MA, Freire NM, Amorim M, Gazeta GS. Epidemiological aspects of the Brazilian spotted fever: seasonal activity of ticks collected in an endemic area in Sao Paulo, Brazil. Revista da Sociedade Brasileira de Medicina Tropical 30:181-185, 1997a.

25. Lemos ER, Machado RD, Pires FD, Machado SL, da Costa LM, Coura JR. Rickettsiae-infected ticks in an endemic area of spotted fever in the State of Minas Gerais, Brazil. Memórias do Instituto Oswaldo Cruz 92: 477-481, 1997b.

26. Lissman BA, Benach JC. Rocky Mountain spotted fever in dogs. Journal American of Veterinary and Medical Association 176: 994-995, 1980.

27. Lodos J, Ochagavia ME, Rodriguez M, De la Fuente J. A simulation study of the effects of acaricides and vaccination on Boophilus cattle-tick populations. Preventive Veterinary Medicine 38: 47-63, 1999.

28. Ministério da Agricultura. Portaria $n^{\circ} 90$ de 04 de dezembro de 1989. Normas para produção e utilização de produtos antiparasitários. In: Diário Oficial, 22 jan, sec1, col 2, 1990.

29. Pérez JN, Godoy AM, Barg L, Costa JO. Isolamento de Brucella canis de carrapatos (Rhipicephalus sanguineus). Arquivo da Escola de Veterinária da Universidade Federal de Minas Gerais 3: 51-56, 1981.

30. Redondo M, Fragoso H, Ortiz M, Montero C, Lona J, Medellin JA, Fria R, Hernandez V, Franco R, Machado H, Rodriguez M, de la Fuente J. Integrated control of acaricide-resistant Boophilus microplus populations on grazing cattle in Mexico using vaccination with Gavac (TM) and amidine treatments. Experimental and Applied Acarology 23: 841-849, 1999.

31. Sartor AA, Cunha DW, Daemon E. Aspectos da biologia de Rhipicephalus sanguineus (Latreille, 1806) (Acari: Ixodidae) em condições de laboratório: Fase parasitária de larvas, ninfas e fêmeas e não parasitária de larvas e ninfas. Revista Brasileira de Medicina Veterinária 18: 14-17, 1996.

32. Sexton DJ, Burgdorfer W, Thomas L, Norment BR. Rocky Mountain spotted fever in Mississippi: survey for spotted fever antibodies in dogs and for spotted fever group Rickettsiae in dog ticks. American Journal Epidemiology 103: 192-197, 1976.

33. Tucci EC, Potenza MR, Dall'Occo PL, Rodrigues CL. Avaliação de extratos vegetais no controle de Dermanyssus gallinae (Degeer, 1778) (Acari, Dermanyssidae). In: Resumos do XVII Congresso Brasileiro de Entomologia, VIII Encontro Nacional de Fitossanitaristas, Rio de Janeiro p.1078, 1998.

34. Ulloa M, Alcaíno H, Gorman T. Esquemas de controle de Rhipicephalus sanguineus en perros de la Región Metropolitana. In: Resúmenes del IX Congreso Nacional de Medicina Veterinaria, Valdivia p.98, 1990

35. Word Health Organization. Seventeenth report of the Committee on Insecticides. In: Technique Reports Series $n^{\circ} 443$, p. 220 224, 1970. 